\title{
Ovario-utero protective effect of silymarin in ethidium bromide treated female rats
}

\author{
H.G. Abdulshaheed ${ }^{1}$, J.A. Al-Sa'aidi2 ${ }^{\circledR}$ and J.K. Al-Arak ${ }^{3}$ \\ ${ }^{1}$ Department of Animal Production, College of Agriculture, ${ }^{2}$ Department of Biochemistry, Physiology and Pharmacology, \\ College of Veterinary Medicine, University of Al- Qadisiyah, Al- Qadisiyah, ${ }^{3}$ Department of Biochemistry, Physiology and \\ Pharmacology, College of Veterinary Medicine, University of Baghdad, Baghdad, Iraq
}

\begin{tabular}{l} 
Article information \\
\hline Article history: \\
Received March 27, 2021 \\
Accepted May 26, 2021 \\
Available online December 19, 2021 \\
\hline Keywords: \\
Ethidium Bromide \\
Silymarin \\
Stress \\
Ovaries \\
Uteri \\
\hline
\end{tabular}

Correspondence:

J.A. Al-Sa'aidi

jabbar.alsaadi@qu.edu.iq

\begin{abstract}
This study was conducted to qualify the ameliorating potency of silymarin against toxicity in ethidium bromide (EtBr) treated female rats. Eighty female Wistar rats aged 100 days, weighted $170-175 \mathrm{~g}$ were randomly allocated to control, orally supplemented with drinking water, and three treated groups, orally supplemented with silymarin 200 $\mathrm{mg} / \mathrm{kg} \mathrm{BW}$, EtBr $10 \mathrm{mg} / \mathrm{kg} \mathrm{BW}$, and combination of EtBr and silymarin (SEtBr), respectively. Each group was allocated to two subgroups, sacrificed after 20 and 40 days of treatment. Bodyweight gain, uteri, and ovaries weight were recorded. Ovarian samples were obtained for histopathological examination. $\mathrm{EtBr}$ group females recorded the lowest body weight gain, relative weights of ovaries and uteri, and ovarian follicle number, whereas $\mathrm{S}$ group females recorded the highest body weight gain and follicular number, while the ovaries and uteri weights were either higher or close to the control group, at both experimental periods. Histopathological findings of both periods revealed necrosis, cirrhosis, ischemia, and prominent hemorrhage in the blood capillaries in EtBr treated ovarian tissues, but many of the ovarian follicles being mature and the atretic follicles were hence found to be high in number, whereas silymarin treated females showed normal ovarian tissues and viable ovarian follicles as that in control females. The combinationtreated females, at 20 days, revealed necrotic primary ovarian follicles with some macrophages infiltration, whereas 40 days' period showed normal ovarian cortex, medulla, and ovarian follicles. In conclusion, silymarin treatment in combination with $\mathrm{EtBr}$ has a potent amelioration effect against ovarian toxicity, in a duration-dependent manner.
\end{abstract}

DOI: 10.33899/ijvs.2021.129798.1688, CAuthors, 2022, College of Veterinary Medicine, University of Mosul.

This is an open access article under the CC BY 4.0 license (http://creativecommons.org/licenses/by/4.0/).

\section{Introduction}

The ovary is a major reproductive gonad that functions as an endocrine gland in addition to being exocrine gland. Any defects that occur in the structure and function of the ovaries leads to a defect in the reproductive function in the mammals, as the ovaries produce oocytes in addition to the production of sex hormones, mainly estrogens (1).

Ethidium Bromide (EtBr) is considered as one of the toxicant sources in the laboratories, acts as an intercalating agent and is broadly used as a stain and a nonradioactive marker in molecular biology laboratory techniques (2). It has been used in treatment of trypanosomiasis in cattle (3).

According to Environmental Health and Safety, EtBr is considered as a potent mutagen, where it acts by intercalating the double stranded DNA and deforms its structure, which inhibits DNA duplication and interrupts protein biosynthesis by inhibiting mitochondrial-associated RNA. 
As EtBr is considered as a toxic and dangerous due to its potency as a mutagenic or teratogenic agent, where it increased glycolytic activity, increased oxidative stress, and mitochondrial ultrastructural changes (4). Silymarin, the main flavonoid and active ingredient of Silybum marianum (milk thistle) fruit and seeds, is considered as a natural antioxidant, which has been commonly used as a phytotherapy for several medicinal applications such as liver disorders (5).

Silymarin contain five active polyphenolic components, silibins and isosilibins, silychristin, silydianin, and isosilychristin as well as one flavonoid (taxifolin) which is a constituent present in the fruits, leaves and seeds of milk thistle, among them silibin is the most active therapeutic potent (6).

In many studies, silymarin and silibin are used in human as hepatoprotective substances, where it has been found that silymarin provide significant protection against experimental hepatotoxicity in laboratory animals. Their effects are related mainly to the anti-oxidative (7), analgesic (8) anti-lipid peroxidative mechanisms, antidiabetic, and hepatoprotective effects (9).

This study aims to examine the ameliorating potency of silymarin against toxic effects of EtBr on female rat ovarian and uterine structure and function.

\section{Materials and methods}

\section{Preparation of silymarin suspension}

Silybum marianum seeds were obtained from the Iraqi local market. The seeds were grinded by electrical grinder. To get the dose of $200 \mathrm{mg} / \mathrm{kg}$ bw (10), the seed powder was suspended in drinking water $(40 \mathrm{~g} / \mathrm{L}$ or $20 \mathrm{mg} / 0.5$ $\mathrm{ml})$. The rats were supplemented with $0.5 \mathrm{ml}$ of suspension/ $100 \mathrm{~g}$ bw.

\section{Experimental animals}

According by guidelines of ethics and policies of the university of Al-Qadisiyah, the current study was conducted by using 80 adult virgin cycling female Wistar rats (aged 100 days and weighted 170-175 g).

The females were housed in a well-controlled hygienic environmental condition (daylight cycles 12L: 12D and temperature around $22-24^{\circ} \mathrm{C}$ ), fed laboratory food pellets (19\% protein and $3000 \mathrm{kcal}$.) and water ad libitum. The females were used only with perfect estrous cycles. The method which has been to determine the estrus phases was described by Marcondes et al. (11).

\section{Experimental design}

Eighty females were randomly divided to four experimental groups (20 females each). Control group (C) was supplemented with $0.5 \mathrm{ml} / \mathrm{kg}$ bw. of drinking water for 40 days, whereas silymarin treated group (S) was supplemented with silymarin $200 \mathrm{mg} / \mathrm{kg}$ bw for 40 days, $\mathrm{EtBr}$ treated group (EtBr) was supplemented with EtBr 10 $\mathrm{mg} / \mathrm{kg} /$ day for 40 days, and combination treated group (SEtBr) was supplemented with both of silymarin and EtBr for 40 days. After 20 and 40 days of treatment, 10 females from each group were weighed and anesthetized by $0.3 \mathrm{ml}$ Ketamine and $0.1 \mathrm{ml}$ of Xylazine/ $\mathrm{kg} \mathrm{BW}$. Ovaries and uteri were obtained and weighted. Ovaries and uteri were incubated fixative solution (10\% alcohol-formalin) for histological study (12).

\section{Statistical analysis}

The results were stated as mean \pm standard deviation where means were compared by ANOVA-1 and NewmanKeuls (13). In the current study, $\mathrm{P}<0.05$ was considered as a significant level in comparison the differences between the means. All statistical analysis was carried out using the GraphPad Prism- Version 5 (SAS Institute, Inc., USA).

\section{Results}

\section{Body weight gain and relative weights of ovaries and uteri}

The finding stated in table 1 represent significant $(\mathrm{P} \leq 0.05)$ upsurge of body weight gain in control, $\mathrm{S}$ and $\mathrm{SEtBr}$ groups started at $20 \mathrm{~d}$. and continued at $40 \mathrm{~d}$., whereas EtBr treated group recorded insignificant $(\mathrm{P} \geq 0.05)$ changes among treatment periods. In comparison among groups for each period, $\mathrm{S}$ group females recorded the highest elevation $(\mathrm{P} \leq 0.05)$ of weight gain, whereas $\mathrm{EtBr}$ group females recorded the lowest elevation $(\mathrm{P} \leq 0.05)$, at both periods. However, SEtBr group body gain was lower $(\mathrm{P} \leq 0.05)$ than control, at both periods. The data showed a significant decrease $(\mathrm{P} \leq 0.05)$ of relative ovarian weight in EtBr treated females among experimental groups at $20 \mathrm{~d}$. period, whereas $40 \mathrm{~d}$. period showed increment $(\mathrm{P} \leq 0.05)$ of that $\mathrm{S}$ group among experimental groups. $\mathrm{SEtBr}$ group recorded insignificant $(\mathrm{P} \geq 0.05)$ changes compared with control, whereas $\mathrm{EtBr}$ females registered the lowest significant $(\mathrm{P} \leq 0.05)$ ovarian weight in comparison with other groups. In comparison between the two periods for each group, the results revealed insignificant $(\mathrm{P} \geq 0.05)$ changes between periods.

Relative uterine weights of $\mathrm{S}$ females (Table 1) revealed insignificant $(\mathrm{P} \geq 0.05)$ elevation, at $20 \mathrm{~d}$. period, and significant $(\mathrm{P} \leq 0.05)$ elevation, at $40 \mathrm{~d}$. period, in comparison with control, but it was higher than that of SEtBr and EtBr females $(\mathrm{P} \leq 0.05)$, at both periods. On the other hand, the two periods revealed insignificant $(\mathrm{P} \geq 0.05)$ changes of uteri weights of control, $\mathrm{S}$ and $\mathrm{SEtBr}$ groups, but $\mathrm{EtBr}$ females reported significantly $(\mathrm{P} \leq 0.05)$ decline, only at $40 \mathrm{~d}$. period. 
Table 1: Relative ovarian and uterine weights of $\mathrm{EtBr}$ induced female rats treated with silymarin

\begin{tabular}{lccccc}
\hline \multirow{2}{*}{ Parameters } & \multirow{2}{*}{ Periods } & \multicolumn{3}{c}{ Groups } \\
\cline { 3 - 6 } & & $\mathrm{C}$ & $\mathrm{S}$ & $\mathrm{EtBr}$ & $\mathrm{SEtBr}$ \\
\hline Body weight gain & $20 \mathrm{~d}$ & $22.8 \pm 3.874^{\mathrm{Bb}}$ & $29.8 \pm 3.860^{\mathrm{Ba}}$ & $5.4 \pm 2.062^{\mathrm{Cc}}$ & $19.8 \pm 2.633^{\mathrm{Bb}}$ \\
(g) & $40 \mathrm{~d}$ & $46.9 \pm 4.331^{\mathrm{Ab}}$ & $56.4 \pm 6.038^{\mathrm{Aa}}$ & $7.3 \pm 2.466^{\mathrm{Cd}}$ & $31.9 \pm 2.807^{\mathrm{Ac}}$ \\
\hline Ovary Relative weight & $20 \mathrm{~d}$ & $9.001 \pm 1.174^{\mathrm{Aa}}$ & $9.218 \pm 1.060^{\mathrm{Aa}}$ & $1.104 \pm 1.063^{\mathrm{Ab}}$ & $8.117 \pm 1.033^{\mathrm{Aab}}$ \\
(mg/100g) & $40 \mathrm{~d}$ & $8.456 \pm 1.031^{\mathrm{Ab}}$ & $9.487 \pm 1.038^{\mathrm{Aa}}$ & $7.312 \pm 1.166^{\mathrm{Ac}}$ & $8.549 \pm 0.807^{\mathrm{Ab}}$ \\
\hline Uterus Relative weight & $20 \mathrm{~d}$ & $0.669 \pm 0.074^{\mathrm{Aab}}$ & $0.743 \pm 0.060^{\mathrm{Aa}}$ & $0.519 \pm 0.062^{\mathrm{Ac}}$ & $0.632 \pm 0.083^{\mathrm{Ab}}$ \\
(g/100g) & $40 \mathrm{~d}$ & $0.632 \pm 0.061^{\mathrm{Ab}}$ & $0.741 \pm 0.076^{\mathrm{Aa}}$ & $0.453 \pm 0.066^{\mathrm{Bc}}$ & $0.611 \pm 0.081^{\mathrm{Ab}}$ \\
\hline
\end{tabular}

$\mathrm{C}$ group: drenched with drinking water. S group: daily supplemented with silymarin suspension $(200 \mathrm{mg} / \mathrm{kg})$. EtBr group: daily drenched with $\mathrm{EtBr}$ solution $(10 \mathrm{mg} / \mathrm{kg})$. SEtBr: daily drenched with EtBr solution $(10 \mathrm{mg} / \mathrm{kg})$ plus silymarin (200 $\mathrm{mg} / \mathrm{kg}$ ). Data were stated as Mean $\pm \mathrm{SD}$. Significance variations between groups $(\mathrm{P} \leq 0.05)$ was presented as different small letters, whereas that between periods was presented as different capital letters.

\section{Ovarian morphometry}

At 20 d. period, ovarian diameter of $\mathrm{S}$ and $\mathrm{SEtBr}$ group females showed insignificant differences, while that of EtBr females decreased significantly compared with that of control, S, and SEtBr group females. At 40 day period, S group females recorded the highest ovarian diameter and $\mathrm{EtBr}$ group females recorded the lowest ovarian diameter among studied groups, whereas control and SEtBr group females showed insignificant difference at this period. Significant increase of ovarian diameter was shown at $40 \mathrm{~d}$. period than 20d. period, in all groups except EtBr group which showed insignificant changes (Table 2).

\section{Uterine morphometry}

At both experimental periods, uterine endometrium thickness of $\mathrm{S}$ and SEtBr females reported insignificant $(\mathrm{P} \geq 0.05)$ changes whereas $\mathrm{EtBr}$ females recorded significant $(\mathrm{P} \leq 0.05)$ decrease than control females, at $40 \mathrm{~d}$. period only. In comparison among experimental periods, all groups reported insignificant $(\mathrm{P} \geq 0.05)$ changes (Table 2$)$. In comparison between experimental group female rats for each period or between experimental periods for each group, insignificant changes were shown in the uterine myometrium thickness (Table 2).

Table 2: Ovarian and uterine morphometry of EtBr induced female rats treated with silymarin

\begin{tabular}{lccccc}
\hline \multirow{2}{*}{ Morphometry } & \multirow{2}{*}{ Periods } & \multicolumn{3}{c}{ Groups } \\
\cline { 3 - 6 } & & $\mathrm{C}$ & $\mathrm{S}$ & $\mathrm{EtBr}$ & $\mathrm{SEtBr}$ \\
\hline \multirow{2}{*}{ Ovarian diameter $(\mu \mathrm{m})$} & $20 \mathrm{~d}$ & $4085 \pm 338^{\mathrm{Ba}}$ & $4255 \pm 473^{\mathrm{Ba}}$ & $2885 \pm 368^{\mathrm{Ab}}$ & $3898 \pm 425^{\mathrm{Ba}}$ \\
& $40 \mathrm{~d}$ & $4496 \pm 369^{\mathrm{Ab}}$ & $4986 \pm 567^{\mathrm{Aa}}$ & $3006 \pm 457^{\mathrm{Ac}}$ & $4212 \pm 337^{\mathrm{Ab}}$ \\
\hline \multirow{2}{*}{ Uterine endometrium $(\mu \mathrm{m})$} & $20 \mathrm{~d}$ & $655 \pm 83^{\mathrm{Aa}}$ & $695 \pm 79^{\mathrm{Aa}}$ & $504 \pm 86^{\mathrm{Ab}}$ & $666 \pm 79^{\mathrm{Aa}}$ \\
& $40 \mathrm{~d}$ & $676 \pm 77^{\mathrm{Aa}}$ & $737 \pm 73^{\mathrm{Aa}}$ & $511 \pm 81^{\mathrm{Ab}}$ & $672 \pm 82^{\mathrm{Aa}}$ \\
\hline \multirow{2}{*}{ Uterine myometrium $(\mu \mathrm{m})$} & $20 \mathrm{~d}$ & $273 \pm 75^{\mathrm{Aa}}$ & $281 \pm 81^{\mathrm{Aa}}$ & $265 \pm 73^{\mathrm{Aa}}$ & $279 \pm 89^{\mathrm{Aa}}$ \\
& $40 \mathrm{~d}$ & $278 \pm 69^{\mathrm{Aa}}$ & $269 \pm 83^{\mathrm{Aa}}$ & $258 \pm 86^{\mathrm{Aa}}$ & $271 \pm 85^{\mathrm{Aa}}$ \\
\hline
\end{tabular}

C group: drenched with drinking water. S group: daily supplemented with silymarin suspension $(200 \mathrm{mg} / \mathrm{kg})$. EtBr group: daily drenched with $\mathrm{EtBr}$ solution $(10 \mathrm{mg} / \mathrm{kg})$. SEtBr: daily drenched with EtBr solution $(10 \mathrm{mg} / \mathrm{kg})$ plus silymarin $(200$ $\mathrm{mg} / \mathrm{kg})$. Data were stated as Mean $\pm \mathrm{SD}$. Significance variation between groups $(\mathrm{P} \leq 0.05)$ was presented as different small letters, whereas that between periods was presented as different capital letters.

\section{Primary follicles}

At $20 \mathrm{~d}$. periods, the number of primary follicles of control and SEtBr group females showed insignificant changes while that of EtBr females recorded significant decrease than control, S, and SEtBr group females. At $40 \mathrm{~d}$. period, $S$ group females recorded the highest number among studied groups followed by control group and then $\mathrm{SEtBr}$ group, whereas EtBr group recorded the lowest significant number. When comparing between experimental periods, $\mathrm{S}$ females recorded significant increase whereas $\mathrm{SEtBr}$ and $\mathrm{EtBr}$ group females recorded significant decline in the number at $40 \mathrm{~d}$. period compared with $20 \mathrm{~d}$. period (Table 3).

\section{Secondary follicles}

At both experimental periods, the number of secondary follicles of $\mathrm{S}$, control and $\mathrm{SEtBr}$ groups reported insignificant changes while $\mathrm{EtBr}$ group recorded significant decrease than all other groups.

When comparing between studied periods, all groups reported insignificant changes in the ovarian diameter (Table 3). 


\section{Graffian follicles}

The result of the Graffian follicle number, clarified in table 3, revealed elevation $(\mathrm{P} \leq 0.05)$ in silymarin treated females and decline $(\mathrm{P} \leq 0.05)$ in EtBr treated females in comparison with control females, at both experimental periods, whereas a combination treatment $(\mathrm{SEtBr})$ revealed insignificant $(\mathrm{P} \geq 0.05)$ changes compared with control. On the other hand, all studied groups showed insignificant $(\mathrm{P} \geq 0.05)$ changes among the two periods.

\section{Total ovarian follicles}

As illustrated in table 3 , the total number of ovarian follicles in $\mathrm{S}$ group females elevated significantly $(\mathrm{P} \leq 0.05)$ than control females, and those treated with $\mathrm{EtBr}$ declined significantly $(\mathrm{P} \leq 0.05)$ than control females, at both experimental periods, whereas that of $\mathrm{SEtBr}$ females revealed insignificant $(\mathrm{P} \geq 0.05)$ changes compared with control. On the other hand, all studied groups showed insignificant $(\mathrm{P} \geq 0.05)$ changes among the periods.

Table 3: Number of ovarian follicles of EtBr induced female rats treated with silymarin

\begin{tabular}{lccccc}
\hline \multirow{2}{*}{ Type of follicle } & \multirow{2}{*}{ Periods } & \multicolumn{4}{c}{ Groups } \\
\cline { 3 - 6 } & & $\mathrm{C}$ & $\mathrm{S}$ & $\mathrm{EtBr}$ & $\mathrm{SEtBr}$ \\
\hline \multirow{2}{*}{ Primary } & $20 \mathrm{~d}$ & $11.66 \pm 1.23^{\mathrm{Ab}}$ & $13.33 \pm 1.17^{\mathrm{Ba}}$ & $8.23 \pm 1.12^{\mathrm{Ac}}$ & $10.87 \pm 1.08^{\mathrm{Ab}}$ \\
& $40 \mathrm{~d}$ & $11.83 \pm 1.18^{\mathrm{Ab}}$ & $14.76 \pm 1.03^{\mathrm{Aa}}$ & $5.37 \pm 1.09^{\mathrm{Bd}}$ & $9.73 \pm 1.07^{\mathrm{Bc}}$ \\
\hline \multirow{2}{*}{ Secondary } & $20 \mathrm{~d}$ & $5.82 \pm 0.44^{\mathrm{Aa}}$ & $5.63 \pm 0.53^{\mathrm{Aa}}$ & $1.87 \pm 0.44^{\mathrm{Ab}}$ & $6.13 \pm 0.67^{\mathrm{Aa}}$ \\
& $40 \mathrm{~d}$ & $5.91 \pm 0.69^{\mathrm{Aa}}$ & $5.54 \pm 0.67^{\mathrm{Aa}}$ & $1.66 \pm 0.39^{\mathrm{Ab}}$ & $6.08 \pm 0.78^{\mathrm{Aa}}$ \\
\hline \multirow{2}{*}{ Graffian } & $20 \mathrm{~d}$ & $8.41 \pm 1.01^{\mathrm{Ab}}$ & $12.35 \pm 1.21^{\mathrm{Aa}}$ & $1.27 \pm 0.36^{\mathrm{Ac}}$ & $7.98 \pm 0.59^{\mathrm{Ab}}$ \\
& $40 \mathrm{~d}$ & $8.88 \pm 1.12^{\mathrm{Ab}}$ & $13.92 \pm 1.19^{\mathrm{Aa}}$ & $1.06 \pm 0.51^{\mathrm{Ac}}$ & $8.47 \pm 0.63^{\mathrm{Ab}}$ \\
\hline \multirow{2}{*}{ Total } & $20 \mathrm{~d}$ & $25.82 \pm 3.65^{\mathrm{Ab}}$ & $30.53 \pm 4.21^{\mathrm{Aa}}$ & $11.24 \pm 3.08^{\mathrm{Ac}}$ & $24.97 \pm 3.87^{\mathrm{Ab}}$ \\
& $40 \mathrm{~d}$ & $26.53 \pm 3.11^{\mathrm{Ab}}$ & $33.55 \pm 3.89^{\mathrm{Ba}}$ & $8.96 \pm 2.76^{\mathrm{Bc}}$ & $24.78 \pm 4.55^{\mathrm{Ab}}$ \\
\hline
\end{tabular}

C group: drenched with drinking water. S group: daily supplemented with silymarin suspension $(200 \mathrm{mg} / \mathrm{kg})$. EtBr group: daily drenched with $\mathrm{EtBr}$ solution $(10 \mathrm{mg} / \mathrm{kg})$. SEtBr: daily drenched with EtBr solution $(10 \mathrm{mg} / \mathrm{kg})$ plus silymarin $(200$ $\mathrm{mg} / \mathrm{kg})$. Data were stated as Mean $\pm \mathrm{SD}$. Significance variation between groups $(\mathrm{P} \leq 0.05)$ was presented as different small letters, whereas that between periods was presented as different capital letters.

\section{Histopathological changes in ovaries}

Twenty days treatment period of Ethidium bromide treated female rats showed sever hemorrhage and necrosis of the ovarian tissues, particularly in the granulosa cells and secondary follicles, cirrhosis, and ischemia), but mostly viable and intact oocytes and cortical tissue surrounded by stroma is shown. Silymarin treated female rats showed normal tissue and normal secondary follicle layers, theca interna, zona granulose, antrum, zona pellucid and oocyte in comparison with control. Furthermore, the total number of atretic follicles was hence found to be higher in Ethidium bromide treated ovarian tissues as compared with control and silymarin treated groups. Ovarian tissues from combination treated female rats showed mixture of intact and necrotic ovarian cortex and medulla, necrotic primary follicles but some of the ovarian follicles still viable, and infiltration of some macrophages are also shown (Figure 1). Control female rats (Figure-2: A and B) showed normal ovarian tissues and normal follicular layers, theca interna, zona granulose, antrum, zona pellucid and oocyte. Forty days treatment period of Ethidium bromide treated female rats (Figure-2: C and D) revealed pronounced degenerative changes in ovarian texture. Furthermore, sloughing, cytolysis and general necrosis and vaculation are shown in the follicles. Few number of mature follicles were seen. Furthermore, a complete destructed follicle also seen in this group. Silymarin treated female rats (Figure-2: E and F) showed normal ovarian tissues. Ovarian tissues from combination treated female rats (Figure-2: $\mathrm{G}$ and $\mathrm{H}$ ) showed showed normal ovarian tissue (primary cortex and medulla), all the ovarian follicles are viable and no hemorrhage or inflammation is seen.

\section{Histopathological changes in uteri}

Twenty days treatment period, uterine tissues of Ethidium bromide treated female rats revealed pathological changes including endometritis and presence abundant plasma cells, which is a diagnostic feature of endometritis when compared with silymarin treated female rats and control female rats, where these groups shared the same normal uterine lining epithelial tissue and normal uterine glands. The results showed a protective effect of the silymarin against the ethidium bromide toxicity, where the uterine tissue, including epithelial lining, strromal cells and uterine glands are still viable and normal during this period of the experiment (Figures 3). Forty days treatment period, uterine tissues of Ethidium bromide treated female rats showed chronic endometritis and and abundant infiltration of plasma cells beneath the epithelial tissue (Figures 4) compared with silymarin treated females (Figures 3) and control female rats (Figures 3), where these groups shared normal uterine lining epithelial tissue and normal uterine glands. The combination treated group confirmed the protective effect of silymarin on the uterus, where uterine tissue revealed no observed pathological changes and all uterine layers still normal and viable (Figures 4: $\mathrm{G}$ and $\mathrm{H}$ ). 

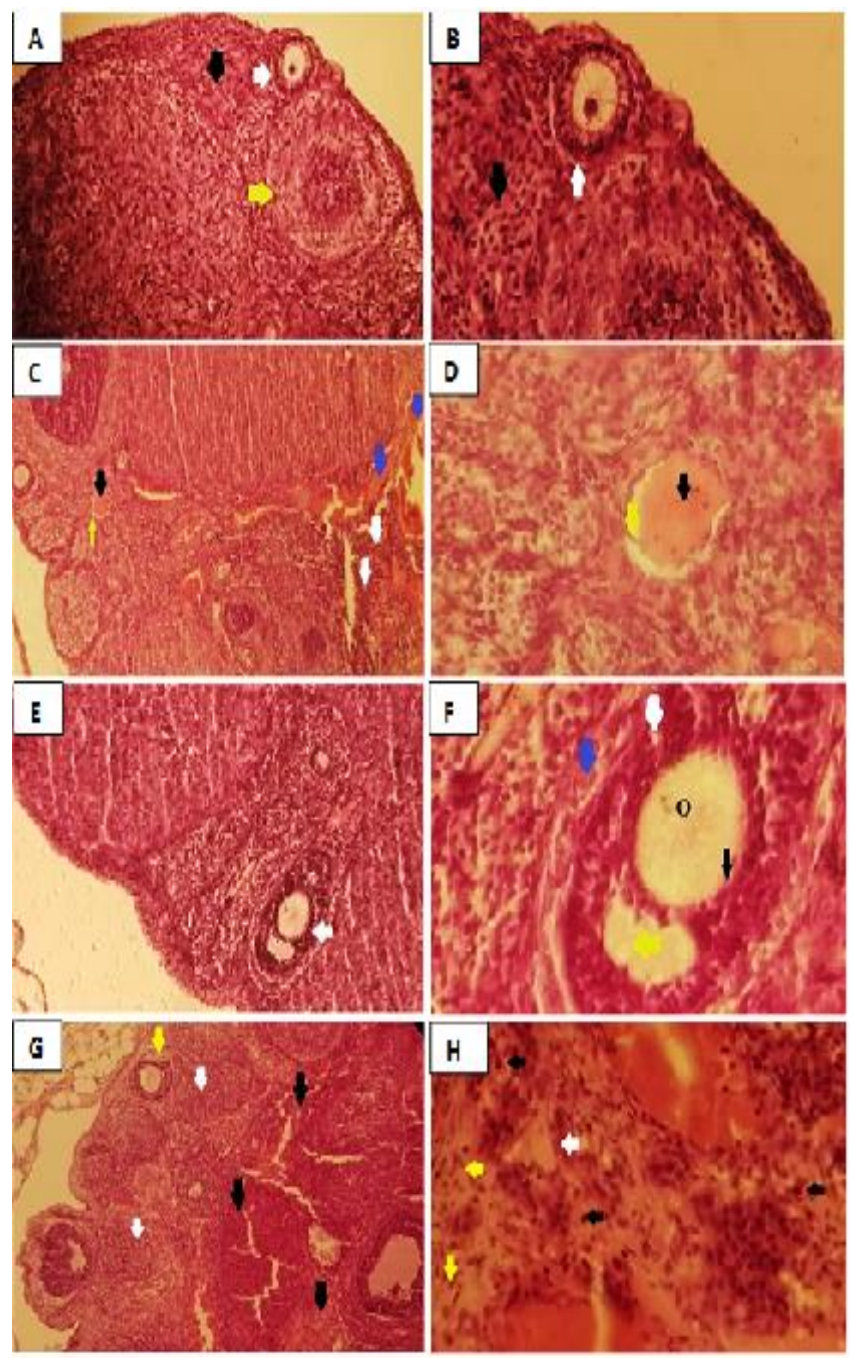

Figure 1: Ovarian sections from 20 days period. A and B: Control ovary shows normal ovarian cortex (black arrow) and viable primary (yellow arrow) and secondary (white arrow) follicles, H\&E, X100 and X400, respectively. C and $\mathrm{D}$ : EtBr treated ovary shows severe hemorrhage (blue arrows) and necrosis (white arrows), necrosis of granulosa cells (yellow arrow) of the secondary follicle (black arrow) but mostly viable and intact oocytes and cortical tissue surrounded by stroma, H\&E, X100 and X400, respectively. E and F: Silymarin treated ovary shows normal tissue and normal secondary follicle layers, theca interna (blue arrow), zona granulose (white arrow), antrum (yellow arrow), zona pellucid (black arrow) and Oocyte (O). H\&E, X400. G: Combination treated ovary shows mixture of intact (white arrows) and necrotic (black arrows) ovarian cortex and medulla, but some of the ovarian follicles still viable (yellow arrow). H\&E, X100. H: Combination treated ovary shows necrotic ovarian tissue (yellow arrows), necrotic primary ovarian follicle (white arrow) and infiltration of some macrophages (black arrows). H\&E, X400.
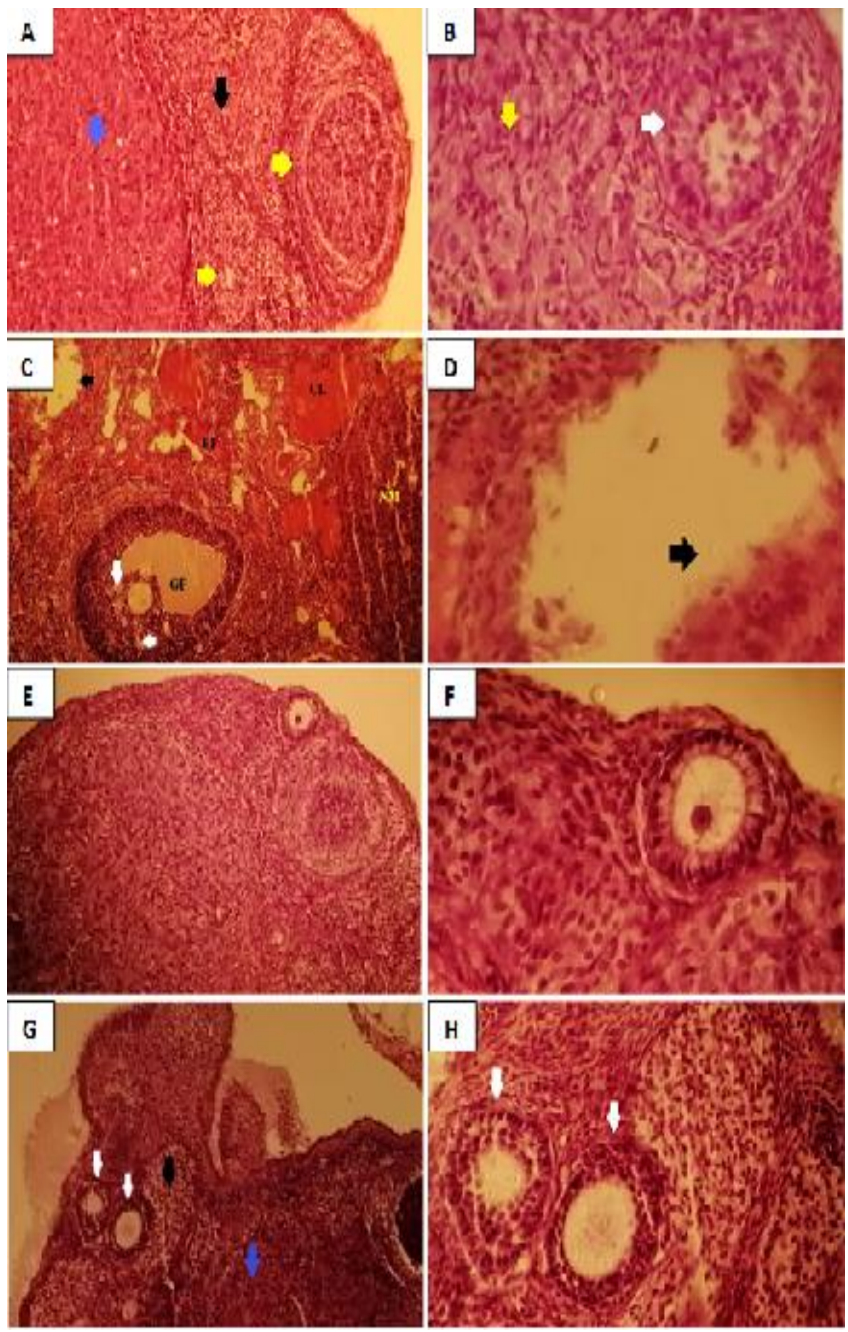

Figure 2: Ovarian sections from 40 days period. A and B: Control ovarian tissue Shows normal ovarian cortex (black arrow) and medulla (blue arrow), also presence of normal ovarian follicles (yellow arrows) and viable ovarian follicles (white arrows), H\&E, X100 and X400, respectively. $\mathrm{C}$ : $\mathrm{EtBr}$ treated ovary shows complete destruction and necrosis of some ovarian follicles (black arrow), as well as wide spread necrosis of medulla (NM) and corpus luteum (CL), mature necrotic and vacculated (white arrows) graafian follicle (GF), and atretic follicle (EF) are obvious in the section surrounding by stroma. $\mathrm{H} \& \mathrm{E}, \mathrm{X} 100$. D: EtBr treated ovary shows complete destruction and necrosis of some ovarian follicles (black arrow). H\&E, X400. E and F: Silymarin treated ovary shows normal ovarian tissue (primary cortex and medulla) and there are primary and secondary follicles, H\&E, X100 and $\mathrm{X} 400$, respectively. $\mathrm{G}$ and $\mathrm{H}$ : Combination treatment ovary shows normal ovarian tissue (cortex and medulla) and there are primary and secondary follicles (white arrows) no hemorrhage or inflammation is seen, H\&E, $\mathrm{X} 100$ and X400, respectively. 

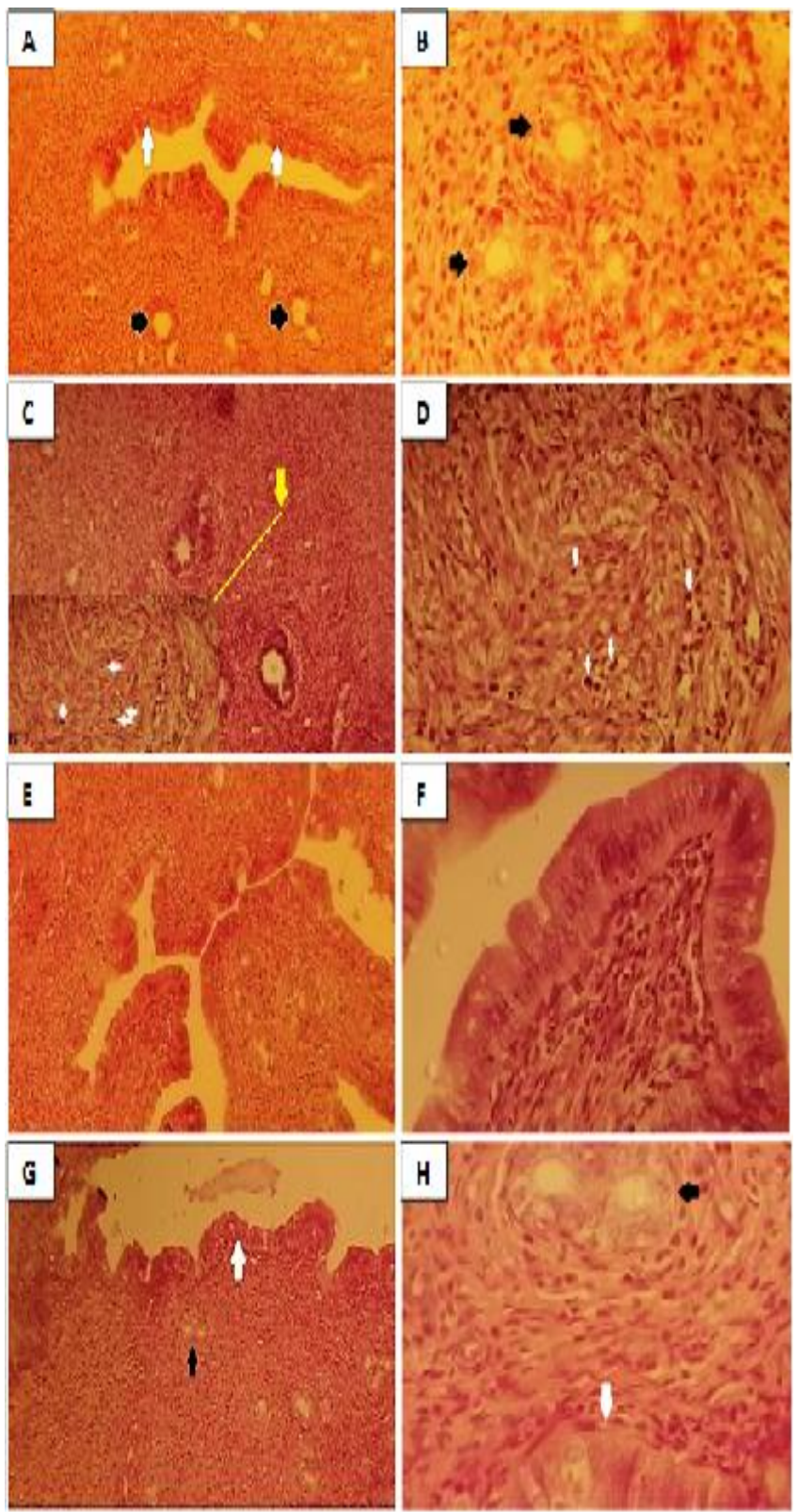

Figure 3: Uteri sections from 20 days period. A and BControl uterus tissue shows normal uterine tissue, the epithelial lining is normal (white arrow), and the uterine glands (black arrow), H\&E, X100 and X400, respectively. $\mathrm{C}$ - and $\mathrm{D}$ - EtBr treated uterus shows endometritis (black arrow) and abundant plasma cells (white arrows) which is a diagnostic feature of endometritis H\&E, X100 and X400, respectively. E- and F- Sylimarin treated uterus shows normal uterus tissue shows normal simple columnar tissue of the endometrium and normal uterine glands H\&E, X100 and X400, respectively. G- and H- Combination treated uterus shows normal uterine tissue, the epithelial lining is normal (white arrow), also the uterine glands (black arrow). $\mathrm{H} \& \mathrm{E}, \mathrm{X} 100$ and X400, respectively.
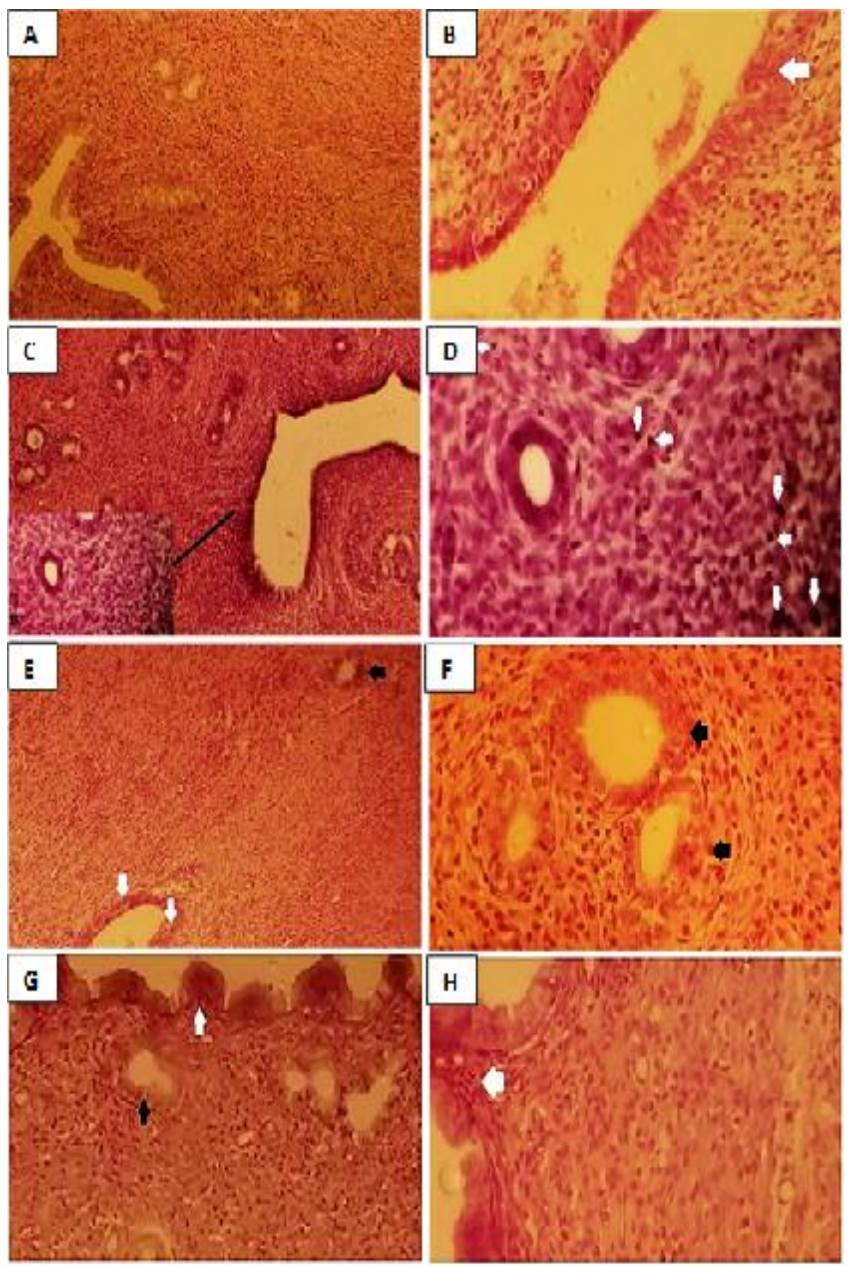

Figure 4: Uteri sections from 40 days period. A and BControl uterus tissue shows Normal uterus tissue shows normal simple columnar tissue (white arrows) and normal uterine glands, H\&E, X100 and X400, respectively. C- and $\mathrm{D}-\mathrm{EtBr}$ treated uterus shows chronic endometritis (X100) and presence abundant plasma beneath epithelial layer in the stroma (X400) as well as abundant plasma cells (white arrows) which is a diagnostic feature of endometritis, $\mathrm{H} \& \mathrm{E}$, X100 and X400, respectively. E- and F- Sylimarin treated uterus shows normal uterine tissue, normal simple columnar tissue (white arrows) and normal uterine glands (black arrows), H\&E, X100 and X400, respectively. G- and $\mathrm{H}-\mathrm{Combination}$ treated uterus shows normal uterine tissue, the epithelial lining is normal (white arrow), also the uterine glands (black arrow), H\&E, X100 and X400, respectively.

\section{Discussion}

The significant increase in the body weight gain of silymarin treated groups might be attributes to the stabilization action of silymarin to the hepatocytes 
membranes, which exerted protection to the hepatocytes and improved liver function. Moreover, the stimulatory action of RNA and protein synthesis shown by silymarin could be subsequently improved growth and increased body weight gain (14). Furthermore, many researchers have suggested the stimulatory action of silymarin by increasing the transcription of ribosomal RNA. Elevated ribosomal production and accelerated protein and DNA biosynthesis could be improving the biosynthesis of structural and functional proteins. Moreover, the stimulatory effect of silymarin may offer more transporters and enzymes, which could enhance different body cells functions (14). Decreased body weight gains in $\mathrm{EtBr}$ treated female rats might be associated with the increased oxidative stress, since $\mathrm{EtBr}$ toxicity leads to cellular antioxidant defense capacity overloading. At this time, reactive oxygen species begin to attack the cellular macromolecules such as DNA, lipids and proteins in addition to cellular amino acids stores (15). Therefore, the alteration of oxidative status will significantly oxidize the amino acids pool, whereas lipids and proteins will be significantly affected in parallel with cytotoxicity. Conversely, improvement achieved by the protection role of silymarin against $\mathrm{EtBr}$ toxicity, in combination treatment group. This might be due to the means of the stable antioxidant activities of both sets of enzymatic and non-enzymatic antioxidants. Accordingly, significant body weight gain improvement achieved in both groups that treated with silymarin.

Improvement of ovarian and uterine weights of silymarin treated groups in this investigation might be attributes to the improvement of pituitary-gonadal axis. Askaripour et al. (16) mentioned that the gonadotrophiclike effects of many herbal extracts can perform many biological actions, including elevated ovarian and uterine relative weight, induction of ovulation, and stimulation of steroidogenic and protein biosynthesis pathways. Moreover, it has been stated that the natural antioxidants of herbal sources have a modulatory effect to treat abnormal hormone secretions accompanying with oxidative stress (17), where the previous findings revealed potent activity of silymarin as an antioxidant which could directly scavenge the increased free radicals caused by EtBr repro-toxicity, inactivate them, and repair the damage (18). Furthermore, this result might be attributes to the role of silymarin to increase ovarian estrogen production, as ovarian sex hormones (estradiol and progesterone) work together in a precise and coordinated mechanism in the control of ovarian functions, including folliculogenesis, oogenesis, the estrous cycle, sexual behavior and ovulation, as the biosynthesis and action of the hormones can be modified by endogenous and/or exogenous factors (19). In the present study, EtBr has been investigated as an exogenous stressful factor, which could play as an inhibitory effector on hypothalamus-pituitary-ovarian axis, whereas silymarin has been investigated alone or in combination with $\mathrm{EtBr}$, as an exogenous ameliorating factor, which could play as a stimulatory effector on hypothalamus-pituitary-ovarian axis.

The positive role of silymarin reflected on the size and number of growing and total ovarian follicles, that shown in silymarin treated group, however $\mathrm{EtBr}$ treated group showed opposite results. Previous reports mentioned that oxygen deprivation is important to stimulate follicular angiogenesis and thus adequate follicular growth and development of the ovaries, in contrast follicular reactive oxygen species promotes apoptosis (20). The role of silymarin, in $\mathrm{S}$ and $\mathrm{SEtBr}$ groups, could be causes improvement of GSH and FSH levels, which could be counterbalances the free radicals in the growing follicle. Moreover, this could be associates with estradiol secretion and therefor increases the response of ovarian granulosa cells to FSH, which could trigger catalase production in the ovarian follicles, and preventing apoptosis (20). In $\mathrm{EtBr}$ treated females, the antioxidant depletion could be a result of excessive oxidative stress and this status could leads to lipid peroxidation which in turn could affect the production of estrogen from ovarian follicles. Supplementation of $\mathrm{EtBr}$, therefor, could decrease the production of glycoproteins and steroid hormones from the ovarian follicles, which might causes infertility. Previously reported, in mammals, that structural proliferation of gonadal and uterine tissues has been detected after treatment with estrogenic activity flavonoids (21). These results were in agreement with the present results since uterine endometrial epithelium showed hypertrophy with tall columnar cells and the size and the number of uterine glands have increased. These observations accompanied by increased number of Graffian follicles and total ovarian follicles.

The decline of relative ovarian weight in $\mathrm{EtBr}$ treated group could be due to the toxic effect of $\mathrm{EtBr}$, where it increases the oxidative stress. This declined of ovarian weight was associated with histopathological changes, including necrosis, degeneration, ischemia and pronounced hemorrhage of the ovary. Other ovarian sections revealed marked degeneration of ovarian histological architecture. These pathological alterations could be due to nuclear degeneration, chromatolysis, rupture and dissolution of nuclear membrane. Mitochondria DNA impairment could be a result of increased reactive oxygen species levels, as mitochondrion is the main site of ROS production (22). Due to the high number of mitochondria and high mitotic activity of granulosa cells, it can be hypothesizes that mitochondrial damage will lead to elevated reactive oxygen species and induction of oxidative stress (20). So elevated reactive oxygen species associated mitochondrial damage due to EtBr treatment may be implicates in cell apoptosis or decreased granulosa cell division during folliculogenesis. Silymarin act as an exogenous antioxidant and inducer of endogenous antioxidants by away of concentration- 
dependent (23). Previous studies mentioned that the protective efficiency of silymarin could be attributes to its disability of the cycle of cyclooxygenase and leukotriene actions (20). Also, the phenolic property of silymarin acts to stabilize the free radicals and ROS by donation them electron and therefor preventing lipo-peroxidation by assistance the communication with cellular non-enzymatic antioxidants (24). A developed antioxidant system has been found in the reproductive organs (25), particularly gonads, where this antioxidants have a vital role in protecting reproductive tissues against free radicals and, in turn, preventing their negative effects on reproduction (20). On the other hand, different herbal extracts and herbal-derived substances have protective effects in the reproductive system. From these herbal extracts, Silymarin was considered as a potent antioxidant agent that can protect most of the biological tissues, including reproductive tissues, such as germ cells (25).

\section{Conclusion}

In conclusion, $\mathrm{EtBr}$ can be responsible for the ovarian and reproductive dysfunction, due to induction of oxidative stress. On the other hand, the harmful action of this toxicity however can be counteracted by induction of endogenous antioxidants or supplementation of exogenous antioxidants. In this study, silymarin has shown beneficial detoxifying activities including improvement of ovarian structure and function.

\section{Acknowledgments}

We would like to thank the deanery of the College of Veterinary Medicine, University of Al-Qadisiyah to support current study.

\section{Conflict of interest}

No conflict.

\section{References}

1. Christensen A, Bentley GE, Cabrera R, Ortega HH, Perfito N, Wu TJ, Micevych P. Hormonal regulation of female reproduction. Horm Metab Res. 2012;44(8):587-591. DOI: 10.1055/s-0032-1306301

2. Zhang C, Liu L, Wang J, Rong F, Fu D. Electrochemical degradation of ethidium bromide using boron-doped diamond electrode. Sep Purif Technol. 2013;107:91-101. DOI: 10.1016/j.seppur.2013.01.033

3. Stevenson P, Sones KR, Gicheru MM, Mwangi EK. Comparison of isometamidium chloride and homidium bromide as prophylactic drugs for trypanosomiasis in cattle at Nguruman, Kenya. Acta Trop. 1995;9(2):257-258. DOI: $10.1016 / 0001-706 X(94) 00080-\mathrm{K}$

4. Nacarelli T, Azar A, Sell C. Inhibition of mTOR prevents ROS production initiated by ethidium bromide-induced mitochondrial DNA depletion. Front Endocrinol. 2014;122:5. DOI: 10.3389/.2014.00122

5. Ahmed MA, Tayawi HM, Ibrahim MK. Protective effect of Silymarin against kidney injury induced by carbon tetrachloride in male rats.
Iraqi $\mathbf{J} \quad$ Vet Sci.

2019;33(1):127-130.

DOI:

10.33899/ijvs.2019.125529.1051

6. Bijak M. Silybin a major bioactive component of milk thistle (Silybum marianum L. gaernt.); chemistry, bioavailability and metabolism. Molecul. 2017;22(11):19442. DOI: 10.3390/molecules22111942

7. Al-Sa'aidi JA, Shoabith HJ. Sequential changes of serum and liver Subcellular oxidants and antoxidant concentrations in silymarin treated male rats. Iraqi $\mathrm{J}$ Vet Sci. 2016;30(1):9-14. DOI: 10.33899/ijvs.2016.116862

8. Naser AS, Albadrany Y. Analgesic effect of silymarin in chicks. Iraqi J Vet Sci. 2019;33(2):273-276. DOI: 10.33899/ijvs.2019.162906

9. Tagmohammadi A, Razavi BM, and Hosseinzadeh H. Silybum marianum (milk thistle) and its main constituent, silymarin, as a potential therapeutic plant in metabolic syndrome: A review. Phytother Res. 2018;2(10):1933-1949. DOI: 10.1002/ptr.6153

10. Capasso R, Aviello G, Capasso F, Borrelli F. Silymarin BIO-C®, an extract from Silybum marianum fruits, induces hyperprolactinemia in intact female rats. Phytomed. 2009;16(9):839-844. DOI: 10.1016/j.phymed.2009.02.007

11. Marcondes FK, Bianchi FJ, Tanno AP. Determination of the estrous cycle phases of rats: Some helpful considerations. Braz J Biol. 2002;62(4):609-614. DOI: 10.1590/S1519-69842002000400008

12. Luna LG. Manual of histological staining methods. $3^{\text {rd }}$ ed. Sydney: McGraw Hill Book Company; 1968. 258 p.

13. Schefler WC. Statistics for biological sciences. $2^{\text {nd }}$ ed. USA: AddisonWesley; 2000. $230 \mathrm{p}$.

14. Abdel-Moneim AM, Elsawy H, Alzahrani AM, Ali A, Mahmoud O. Silymarin ameliorates acrylamide-induced hyperlipidemic cardiomyopathy in male rats. Biol Med Res Internat. 2019;2019:4825075. DOI: 10.1155/2019/4825075

15. Wolf A, Trendelenburg CF, Diez-Fernandez C, Prieto P, Houy S, Trommer WE, Cordier A. Cyclosporine A-induced oxidative stress in rat hepatocytes. J Pharmacol Exp Therapeu. 1997;280(3):1328-1334. [available at]

16. Askaripour M, Hasanpour A, Hosseini F, Moshrefi M, Moshtaghi G, Hasannejad M, Rajabi S, Nematollahi-Mahani S.N. The effect of aqueous extract of Rosa damascena on formaldehyde-induced toxicity in mice testes. Pharm Biol. 2018;56:12-17. DOI: 10.1080/17.1413663

17. Barwarei BA, Sadoon HS. Histopathological and some biochemical effects of platinum drug on the liver and kidney of pregnant mice Mus musculus and their embryos. Iraqi J Vet Sci. 2021;35(2):291-300. DOI: $10.33899 /$ ijvs.2020.126793.1382

18. Nna VU, Abu Bakar AB, Ahmad A, Eleazu CO, Mohamed M. Oxidative stress, NF- $\kappa \mathrm{B}$-mediated inflammation and apoptosis in the testes of streptozotocin-induced diabetic rats: Combined protective effects of Malaysian propolis and metformin. Antioxidants. 2019;8(10):465. DOI: 10.3390/antiox8100465

19. Agarwal A, Aponte-Mellado A, Premkumar BJ. The effects of oxidative stress on female reproduction: A review. Reprod Biol Endocrinol. 2012;10:49. DOI: 10.1186/1477-7827-10-49

20. Noh S, Go A, Kim DB, Park M, Jeon HW, Kim B. Role of antioxidant natural products in management of infertility: A review of their medicinal potential. Antioxidant. 2020;9:957. DOI: 10.3390/100957

21. Santell RC, Chang YC, Nair MG, Helferich WG. Dietary genistein exerts estrogenic effects upon the uterus, mammary gland, and the hypothalamic/pituitary axis in rats. J Nutr. 1997;127:263-269. DOI: $\underline{10.1093 / \mathrm{jn} / 127.2 .263}$

22. Circu ML, Aw TY. Reactive oxygen species, cellular redox systems, and apoptosis. Free Radical Biol Med. 2010;48(6):749-762. DOI: 10.1016/j.freeradbiomed.2009.12.022

23. Radko L, Cybulski W. Application of silymarin in human and animal medicine. J Pre-Clin Clin Res. 2007;1(1):22-26. [available at]

24. Karimi G, Vahabzadeh M, Lari P, Rashedinia M, Moshiri M. Silymarin, a promising pharmacological agent for treatment of diseases. Iran J Basic Med Sci. 2011;14:308-317. [available at]

25. Ismail HK. Histopathological alterations of male and female reproductive systems induced by alloxan in rats. Iraqi J Vet Sci. 2021;35(2):223-226. DOI: $\underline{10.33899 / \text { ijvs.2020.126626.1351 }}$ 


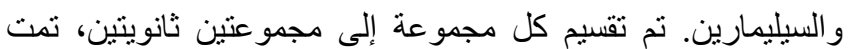

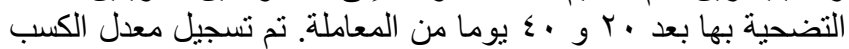

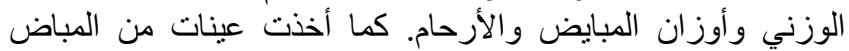

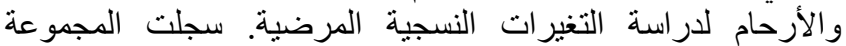

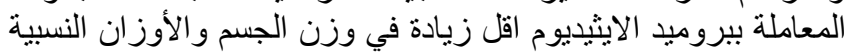

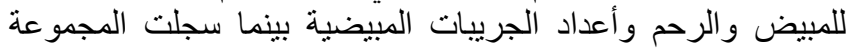

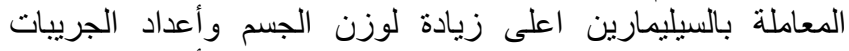

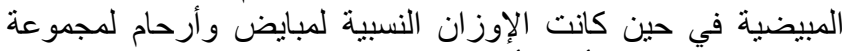

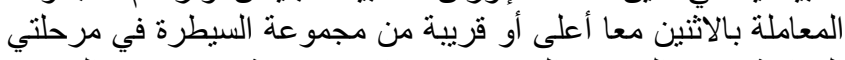

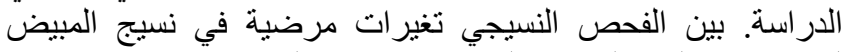

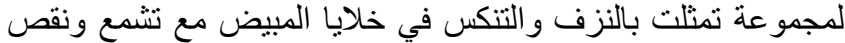

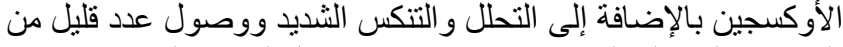

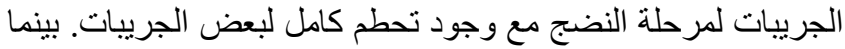

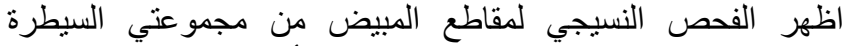

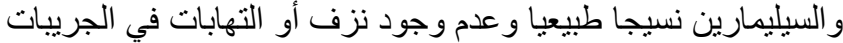

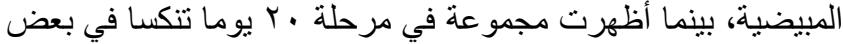

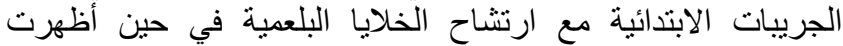

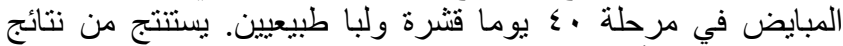

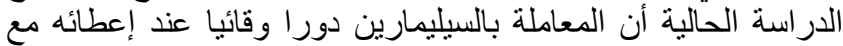

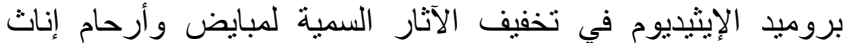

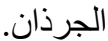

التأثير الوقائي للسيليمارين على مبايض وأرحام

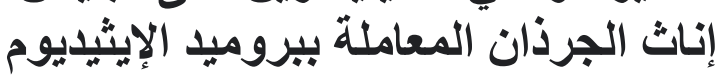

العير آكازي عبدالثهيد'، جبار عباس الساعديץ و جواد كاظم

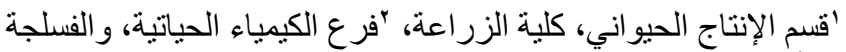

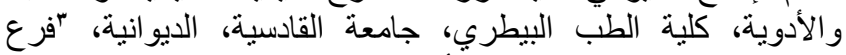

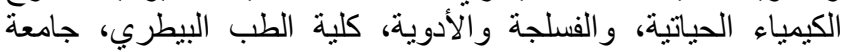

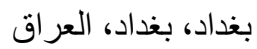

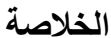

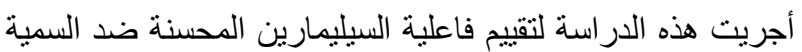

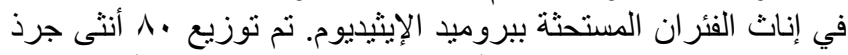

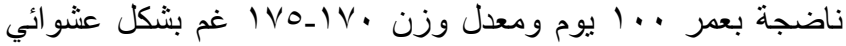

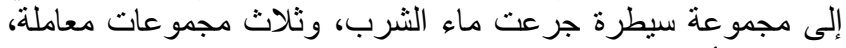

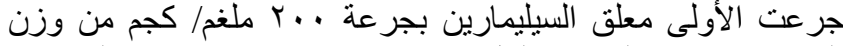

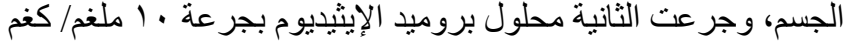

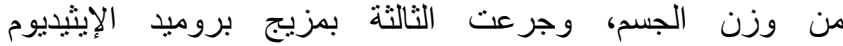

